\title{
RESEARCH PAPER \\ Movement between crops and weeds: temporal refuges for aphidophagous insects in Central Chile
}

\author{
Cinthya M. Villegas ${ }^{1}$, Jaime A. Verdugo ${ }^{1,2}$, Audrey A. Grez ${ }^{3}$, Jaime Tapia ${ }^{4}$, \\ and Blas Lavandero ${ }^{1}$ \\ ${ }^{1}$ Instituto de Biología Vegetal y Biotecnología, ${ }^{4}$ Instituto de Química de Recursos Naturales, Universidad de \\ Talca. 2 Norte 685, Talca, Chile. \\ ${ }^{2}$ Centro Regional de Innovación Hortofrutícola de Valparaíso Ceres. Pontificia Universidad Católica de \\ Valparaíso. Casilla 4-D. Quillota, Chile. \\ ${ }^{3}$ Facultad de Ciencias Veterinarias y Pecuarias, Universidad de Chile, Casilla 2, Correo 15, La Granja, Santiago, Chile.
}

\begin{abstract}
C.M. Villegas, J.A. Verdugo, A.A. Grez, J. Tapia, and B. Lavandero. 2013. Movement between crops and weeds: temporal refuges for aphidophagous insects in Central Chile. Cien. Inv. Agr. 40(2): 317-326. Crop edges have significant effects on populations of natural enemies, acting as source or sink habitats during the growing season. Previous observations have shown that coccinellid species are associated with thistle (Sylibum marianum (L.) Gaertn), a common exotic weed in the central valley of Chile. To determine whether thistles growing at crop edges act as a putative refuge for natural enemies, the seasonal relative abundance of aphidophagous coccinellids was estimated at 0,10 and $25 \mathrm{~m}$ from the edges of three alfalfa fields. Mark-recapture studies were carried out using the trace element rubidium ( $\mathrm{Rb}$ ) to determine whether coccinellids moved between the edges and the alfalfa. The most common aphidophagous coccinellid species were Hippodamia convergens (63\%), H. variegata (11\%), Rhyzobius lophantae (4\%) and Adalia angulifera (4\%). In mid-November, the abundance of coccinellids at the edge of ( $0 \mathrm{~m}$ from the edge) the alfalfa plot increased compared to that at the center of the field ( $25 \mathrm{~m}$ from the edge), coinciding with a reduction in the population of aphids at all sampling points. Of the coccinellids captured at the thistle edge, $68 \%$ were marked with rubidium, suggesting movement of coccinellids from the alfalfa plot to the thistle growing at its edges. After the thistles were removed, coccinellids returned to the crop, as shown by the presence of marked coccinellids within the alfalfa fields at all three sampling distances. The results of this study suggest that thistles can act as a refuge for coccinellids when aphids are not available in the alfalfa fields.
\end{abstract}

Key words: Alfalfa, coccinellids, refuges, rubidium, thistle.

\section{Introduction}

Landscape composition of agricultural areas is often characterized by rapid changes in time and

Received October 10, 2012. Accepted January 22, 2013. Corresponding author: blavandero@utalca.cl space (Thies et al., 2008). The non-farmed areas surrounding agricultural lands are therefore an important component of the stability of agroecosystems. These areas can be putative refuges for predators and can act as an important source of biological control agents (Mensah and Sequeria, 2004). Refuges can enhance the survival, fecun- 
dity, longevity, and behavior of natural enemies, increasing the colonization of crops by such enemies and contributing to the control of pest populations (Landis et al., 2000; Sutherland et al., 2001). Ecologically-based research on biological control by natural-enemy populations requires an understanding of the population dynamics of these species (Gurr et al., 2000) and of their dispersal into the crop from a particular resource or habitat patch (Woodcock et al., 2010; Skirvin et al., 2011). To investigate these processes, it is necessary to assess the movements of natural enemy species. The conditions at each crop location determine whether a natural enemy will disperse from the crop to nearby edges that could act as refuges. Hence, field edges can be important in modulating predator-prey interactions and the control of pest populations within crops (Grez et al., 2005). Habitat fragmentation can affect insect dispersal in the landscape, especially considering modern agricultural practices that modify the landscape significantly, eliminating natural or semi-natural vegetation where insect biological control agents may seek refuge (Grez et al., 2008).

In Chile, alfalfa (Medicago sativa L.) is a highly productive forage crop that supports the development of many insects, including economically important pests such as the pea aphid Acyrthosiphon pisum (Harris) and the blue aphid $A$. kondoi (Shinji) (Devotto and Gerding, 2000). Aphidophagous insects associated with alfalfa, such as coccinellids, are very common and are able to predate aphids at high rates (Grez et al., 2010). Because hemipteran insects such as aphids are a major component of the diets of many coccinellid species in Chile, coccinellids have traditionally been considered good biological control agents (Aguilera et al., 2005). Depending on resource availability, alfalfa may act as a sink for coccinellids (Grez and Prado, 2000), although this typically reverses at the beginning of summer, when aphids in alfalfa become scarce. The conditions at the field edges have been shown to differentially affect the abundance of coccinellid species in alfalfa (Grez et al., 2010). However, it is not clear whether field edges can act as natural enemy refuges that sustain coccinellid populations between disturbances. Previous observations have shown that several introduced coccinellid species are associated with thistle (Sylibum marianum (L.) Gaertn), a common weed encountered along the field edges of alfalfa fields in central Chile.

We hypothesize that as the population density of aphids in an alfalfa crop diminishes aphidophagous species will migrate to the edges of the plot containing the crop and that these species will return to alfalfa as resources again become available. The aim of this study was to assess the seasonal relative abundance of coccinellids and aphids in thistle edges and alfalfa plots and to measure the movement of coccinellids between these two habitats through mark-recapture experiments using rubidium chloride.

\section{Materials and methods}

The experiments were carried out at the Liceo Técnico Agrícola María Auxiliadora in Colín, $9 \mathrm{~km}$ west of Talca, Chile, in three small alfalfa fields adjacent to weedy strips of $S$. marianum. The total surface of the three fields was 6 ha, and approximately $1800 \mathrm{~m}^{2}$ of each field were used for sampling. The three fields had naturally occurring thistle strips in different orientations (two weedy edges were located on the northern side of the first two fields, and one was located on the east side of the third field). During the experiment, other weeds were manually removed to provide thistles as the only edge resource vegetation.

\section{Insect capture}

Wooden stakes with yellow sticky traps were placed 0,10 and $25 \mathrm{~m}$ from the edges of the fields at crop height. The thistle strips represented the field edges. The traps were placed and changed every 15 days to assess the abundance of coccinellids at all three distances. 
The data were collected between September 25 and December 23, 2009. At the same time, 50 sweep-net strokes were made parallel to the field edge at each of the sampling distances to estimate the seasonal abundance of aphids. The material collected in the sweep-nets was kept at $-20{ }^{\circ} \mathrm{C}$ until evaluation. The collected samples were identified and recorded in the laboratory. Identification of the species in the collected samples was carried out using keys from Blackman and Eastop (2000) for aphids and from González (2006) for coccinellids.

Dispersal of coccinellids between alfalfa and thistles

To measure the dispersal of coccinellids between the alfalfa fields and the thistle edges, a solution of rubidium chloride $(\mathrm{RbCl})$ at $2000 \mathrm{ppm}$ (Gaete, 2008) was sprayed with a knapsack sprayer at the center of each alfalfa field. This was performed at the end of spring (November 20,2009) when the aphid numbers were beginning to decrease from their seasonal high (Figure 1a). To maximize the chances of collecting marked insects, the yellow sticky traps 0,10 and $25 \mathrm{~m}$ from the edges of the fields were removed 19 days after the marking of the fields with Rb. Samples from thistles were obtained by tray beating 19 days after $\mathrm{RbCl}$ application to ensure that the collected specimens were actually on the putative refuge. To estimate the subsequent movement of coccinellids from the thistles to the alfalfa, $\mathrm{RbCl}$ was applied a second time at the same dose to all the thistles surrounding the alfalfa fields on December 9, 2009. The thistles were manually removed 14 days later to increase the likelihood that coccinellids would migrate away from the refuge. Prior to the second $\mathrm{Rb}$ application, the aphids and coccinellids in the thistles were counted (without removal) to ensure that there was a sufficient number of insects to mark. To avoid cross-contamination, the samples used to detect movement from the thistles to the alfalfa fields were acquired a month after the first $\mathrm{Rb}$ application (December 23, 2009). Previous laboratory experimental data have shown that after application of $\mathrm{RbCl}$ solution the concentration of rubidium on marked plants and insect decreases quickly with time (Prasifka et al., 2001; Kobelt et al., 2009) and that the concentration of rubidium in the plant tissues is drastically reduced by rain and irrigation (Polavarapu et al., 1992; Long et al., 1998). Therefore, a week prior to the second rubidium application, irrigation was carried out in all fields.
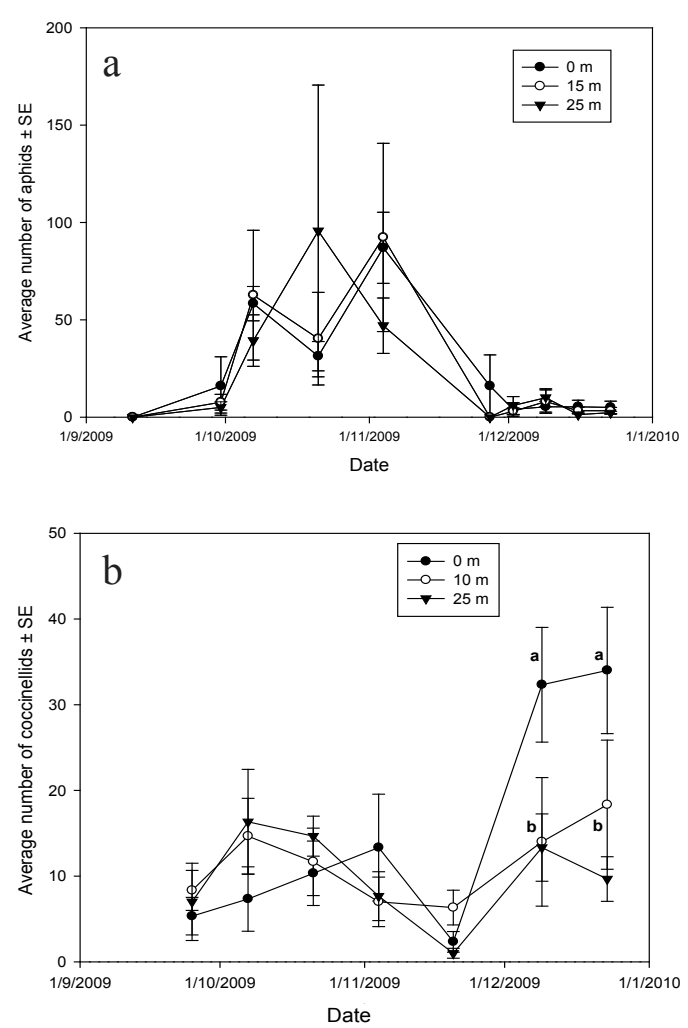

Figure 1. (a) Mean abundance of aphids ( \pm SE) in the three alfalfa fields at 0,10 and $25 \mathrm{~m}$ from the weedy strip on different dates. (b) Mean abundance of coccinellids ( \pm SE) captured with the sticky traps in the three alfalfa fields at 0,10 and $25 \mathrm{~m}$ from the weedy edge on different dates. The letters indicate significant differences at $\mathrm{P} \leq 0.05$ following Tukey's test.

\section{Rubidium concentration analysis}

The rubidium concentrations in the adult coccinellid specimens captured on the two dates (November 23, representing the dispersal between 
alfalfa and thistles, and December 23, representing the movement from thistles to alfalfa) were analyzed. All of the individually collected insects were frozen at $-80{ }^{\circ} \mathrm{C}$ until chemical digestion. Prior to chemical digestion, the samples were dried in an oven at $30{ }^{\circ} \mathrm{C}$ for two days and their dry weight was determined. Chemical digestion was accomplished via a two-step wet oxidation procedure using concentrated nitric acid and hydrogen peroxide following the method described by Prasifka et al. (2001). The digested samples were diluted to $5 \mathrm{ml}$ with ultrapure water, and their rubidium concentrations were estimated using a UNICAM 969 Atomic Absorption Spectrophotometer (AAS). The AAS was calibrated by aspirating controls and adjusting to zero absorbance. Standard solutions were prepared using distilled water containing rubidium chloride with a purity of $99.8 \%$ to obtain a calibration curve. The absorbance of the experimental samples was determined, and the calibration curve was used to calculate their rubidium concentrations as in Prasifka et al. (2001). The spectrophotometric determination of the rubidium content of the samples was based on flame AAS using a wavelength of $780 \mathrm{~nm}$. The total absorbance of each of the calibration standard solutions $(0.5,1,1.5$ and $2 \mathrm{mg} \mathrm{L}^{-1}$ ) was integrated for four seconds. The results were recorded in $\mathrm{mg} \mathrm{L}^{-1}$ of rubidium solution. Ten coccinellid individuals per species, captured before the rubidium applications, were used as blanks. A sample was considered positively labeled if the concentration of rubidium was more than three times the standard deviation of the average base level of the coccinellids caught before $\mathrm{Rb}$ application in the experimental field thus ensuring a conservative threshold with a type I error not exceeding $0.13 \%$ (Lavandero et al., 2005).

\section{Statistical analysis}

The abundance of aphids and coccinellids was analyzed with a generalized linear mixed model (GLMM) assuming a Poisson distribution with the field site, time as a random factor and distance as a fixed factor. Analyses were carried out using the lme4 package by Douglas Bates implemented for R (Fox, 2005). Analyses of the proportion of marked insects were also carried out with GLMM, assuming a binomial distribution with the field site as a random factor and distance as a fixed factor.

\section{Results}

\section{Aphids}

A total of 1,967 aphids were captured with the sweep net in the three alfalfa fields between September and December 2009. The mean abundance of aphids varied significantly with time $(\mathrm{P} \leq 0.0001$; $\mathrm{F}=5.28$ ), reaching a maximum between October $7^{\text {th }}$ and November $4^{\text {th }}$ and declining to very low numbers in early December. There were no significant differences in the mean abundance of aphids at the various sampled distances from the field edge during the sampling period $(\mathrm{P}=0.9591$; $\mathrm{F}=0.81$ ) (Figure 1a).

\section{Coccinellids}

Overall, 1,061 coccinellids of 13 species were collected. These included Coccidulinae (Rhizobius lophantae (Blaisdell)), Scymninae (Cryptoalemus montrouzieri Mulsant, Scymnus (Pullus) bicolor (Germain), S. (Pullus) loewii Mulsant, Hyperaspis sphaeridioides (Mulsant)) and Coccinellinae (Adalia angulifera Mulsant, A. bipunctata (Linnaeus), Cycloneda fulvipennis (Mulsant), Eriopis andina Hofmann, E. connexa (Germar) ssp. chilensis Hofmann, Hippodamia convergens (Guerin-Meneville), H. (Adonia) variegata (Goeze), and Psyllobora picta (Germain)). All of the specimens were captured in the three fields of alfalfa between September and December 2009. In total, 765 coccinellids were captured with yellow sticky traps. The most representative captured species was $H$. convergens, which 
represented $62.6 \%$ of the total sample (Figure 2). The number of captured coccinellids showed a significant effect of distance $(\mathrm{P}=0.0084)$ and of the interaction term (distance-time: $\mathrm{P}=0.0085$; $\mathrm{F}=3.3646$ ). At the earlier dates studied, no differences in the abundance of coccinellids at distances of 0, 10 and $25 \mathrm{~m}$ were found. Significant differences began to occur by November 20th, when the number of coccinellids at the edge of the field $(0 \mathrm{~m})$ increased significantly with respect to the other two sampling distances (Figure 1b).

\section{Rubidium analysis}

A total of 187 coccinellid adults were used in the rubidium content analyses. Only two species, $H$. convergens and $H$. variegata, were found to be positively marked with rubidium ( $\mathrm{Rb}$ concentrations greater than three SD over the background mean $\mathrm{Rb}$ content). The data suggest that there was movement of $H$. convergens and $H$. variegata from the alfalfa field to the thistle edge three days after $\mathrm{Rb}$ application to the alfalfa field (Figure 3). The proportion of marked coccinellids was $0.33 \pm$ $0.6 \%$ at $25 \mathrm{~m}$ from the field edge, $0.33 \pm 0.6 \%$ at
$10 \mathrm{~m}$ from the edge, $0.5 \pm 0.7 \%$ at $0 \mathrm{~m}$ from the edge and $0.68 \pm 0.24 \%$ on the thistles, without any significant differences between these four sampling distances $(\mathrm{P}=0.3412)$.

The proportion of marked coccinellids collected in the alfalfa field after $\mathrm{Rb}$ application to the thistles (December 9th) was $0.23 \pm 0.15 \%$ at $0 \mathrm{~m}$ from the weedy strip, $0.13 \pm 0.26 \%$ at $10 \mathrm{~m}$ from the strip and $0 \%$ at $25 \mathrm{~m}$ from the strip; these values are not statistically significantly different from each other $(P=0.1224)$ (Figure 4$)$.

\section{Discussion}

Disturbances such as the application of pesticides and cutting of alfalfa for forage production can reduce the aphid populations present on crops and can have a substantial impact on the dispersal and survival of the aphids' natural enemies. The use of refuges represents an important potential tool for pest management because refuges have a role in sustaining natural enemies between disturbances and increasing natural enemy colonization thereafter. Therefore, the conservation

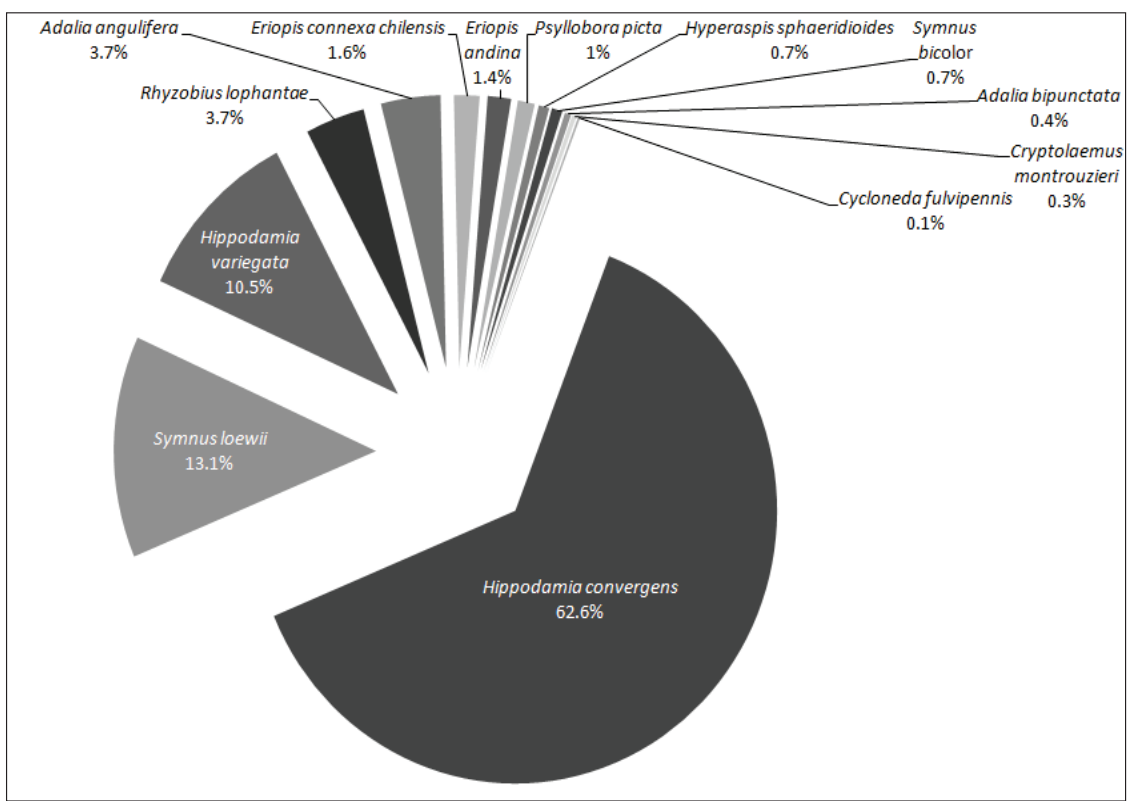

Figure 2. Percentage of each identified species of coccinellid captured on yellow sticky traps during the season. 


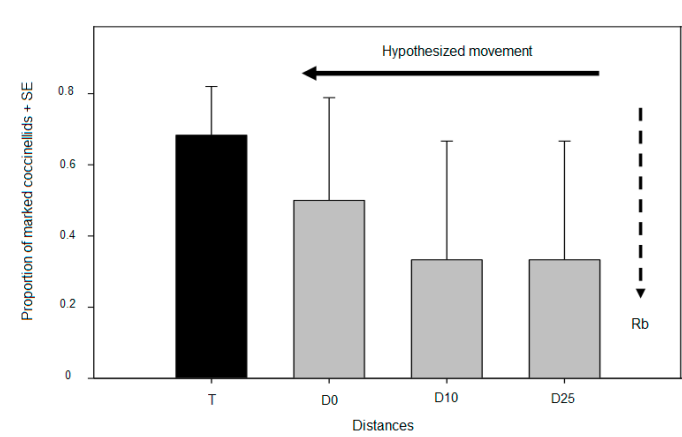

Figure 3. Proportion of marked coccinellids at three distances from the edge of the field $(\mathrm{D} 25=25 \mathrm{~m}$ inside the crop; D10 $=10 \mathrm{~m}$ inside the crop; D $0=0 \mathrm{~m}$ from the edge of the crop; $\mathrm{T}=$ thistles at the edge of the crop). The black bar represents the thistle refuge, and the lighter bars represent various distances from the edge of the field. The black line indicates the hypothesized movement of the coccinellids to the thistles. The black segmented line indicates the position in the field at which the $\mathrm{Rb}$ applications were carried out.

of weedy edges could enhance natural enemy populations, possibly reducing the infestation of commercial crops by pests (Marshall and Moonen, 2002; Schmidt et al., 2004; Burgio et al., 2006). These natural refuges could act as sinks of pests and their natural enemies, providing shelter or alternative foods such as nectar or pollen (Altieri and Nicholls, 2010). In the central valley of Chile, thistle refuges are commonly found adjacent to annual crops, and such refuges offer resources that can be utilized when there is a low supply of prey in the main crop (Grez et al., 2010). To enable informed management decisions, it is important to quantify the effect of these refuges and determine whether they are sources or sinks of natural enemies during the growing season.

The movement of coccinellids is mediated by the food resources on their prey's host- plants (Grez et al., 2010) when the abundance of predators is positively correlated with the abundance of their prey (aphid) populations (Elliot et al., 2002). In the central valley of Chile, aphid populations show two seasonal peaks, one in spring and another in autumn (Grez et al., 2010). During the time period covered in this study, the first peak occurred between October and November (Figure 1a), and

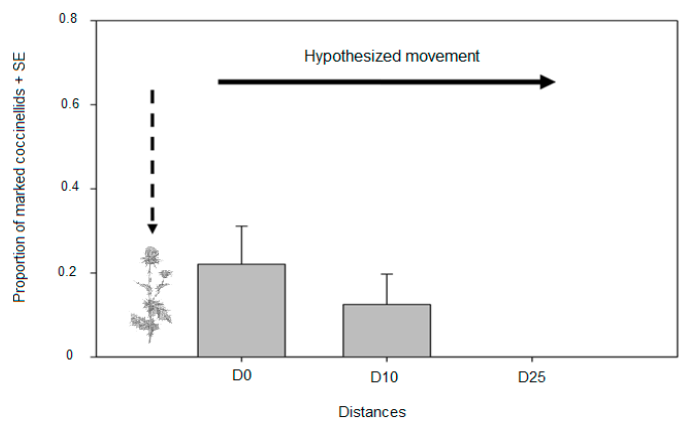

Figure 4. Proportion of marked coccinellids at three distances from the marked thistles located at the edge of the alfalfa fields ( $\mathrm{T}=$ thistles at the edge of the crop, $\mathrm{D} 0=0 \mathrm{~m}$ (edge of the crop), D10 $=10 \mathrm{~m}$ inside the crop, $\mathrm{D} 25=25 \mathrm{~m}$ inside the crop). The lighter bars represent the different distances from the edge to the field. The black line indicates the hypothesized movement of the coccinellids to the alfalfa field. The black segmented line indicates the position in the field at which the applications of $\mathrm{Rb}$ were carried out.

the abundance of aphids subsequently rapidly decreased. The increase in the total coccinellid population at the edges of the fields (Figure 1b) coincided with the decline in aphid population that occurred at the end of November (Table 1; Figure 1a). The decline in the number of aphids seems to be connected with the movement of the coccinellids because $68 \%$ of the collected coccinellids on the thistle edges were positively marked with $\mathrm{Rb}$, which could only have been acquired by feeding on aphids from the center of the alfalfa field (Figure 3). This observation supports the idea that thistles at field edges can act as a refuge after disturbances such as alfalfa tillage, which is an important source of disturbance aphid and coccinellid populations. Mark-recapture studies to assess whether coccinellids leave the field and move to an adjacent refuge when aphids are scarce are needed to inform management decisions. In our study, which suggests that coccinellids moved from the alfalfa field to the thistle edge, shows that as aphid numbers declined coccinellids had to find food resources elsewhere. In fact, field edge thistles were infested with the aphid Uroleucon aeneus (Hule Ris Lambers), a suitable food source for the coccinellids in absence of A. pisum. In addition to aphids, thistles offer pollen that may 
Table 1. Multiple comparisons using Tukey's test with the respective P-values for the mean abundance of coccinellids in the alfalfa field at various times (T) at three different distances (D) from the edge to the center of the alfalfa field: $0 \mathrm{~m}$ (D0), $10 \mathrm{~m}$ (D10) and $25 \mathrm{~m}$ (D25).

\begin{tabular}{|c|c|c|c|c|c|c|c|c|}
\hline & D10-T5 & D25-T5 & D0-T6 & D10-T6 & D25-T6 & D0-T7 & D10-T7 & D25-T7 \\
\hline D0-T5 & 0.67 & 0.99 & $<0.01 *$ & $<0.01^{*}$ & $<0.01^{*}$ & $<0.01^{*}$ & $<0.01^{*}$ & 0.09 \\
\hline D10-T5 & & 0.18 & $<0.01 *$ & 0.42 & 0.57 & $<0.01^{*}$ & $0.03 *$ & 0.99 \\
\hline D25-T5 & & & $<0.01 *$ & $<0.01^{*}$ & $<0.01^{*}$ & $<0.01 *$ & $<0.01^{*}$ & $0.02 *$ \\
\hline D0-T6 & & & & $<0.01 *$ & $<0.01$ * & 1 & 0.82 & $<0.01 *$ \\
\hline D10-T6 & & & & & 1 & $0.0282 *$ & 0.99 & 0.99 \\
\hline D25-T6 & & & & & & $0.0161 *$ & 0.99 & 1 \\
\hline D0-T7 & & & & & & & 0.02 * & $<0.01 *$ \\
\hline D10-T7 & & & & & & & & 0.28 \\
\hline
\end{tabular}

${ }^{*}$ Indicates significant differences at $\mathrm{P} \leq 0.05$. T5 = November 20; T6 = December 9; T7 = December 23. Because no significant differences were found during the period $\mathrm{T} 1-\mathrm{T} 4$, these data have been omitted from the table. Bold letters indicate significant differences between distances within the same sampling times.

serve as an alternative food source for the coccinellids until prey is again available in the crop. Several coccinellid species are known to consume pollen when their prey is scarce; specifically, $A$. bipunctata and $H$. convergens have been shown to be capable of using pollen as an alternative food source (Lundgren, 2009). Whether coccinellids present on the thistle edges return to the crop once these resources are depleted was examined by marking the thistles with rubidium. When the thistles were removed, coccinellids returned to the field, as shown by the presence of a significant amount of marked coccinellids subsequent to the marking of the thistles in the alfalfa fields at all three distances (Figure 4).

The results reported here suggest that thistles act as a potential refuge for coccinellids by harboring aphid prey and/or pollen. The mark-recapture data presented in this paper suggest that coccinellids return to alfalfa when the refuge is no longer attractive due to the reduction of aphid numbers on the thistles, the natural senescence of the weeds or an increase in the aphid population within the crop. Complex landscapes that improve the connectivity between uncultivated and cultivated lands can act as reservoirs of natural enemies (Scherber et al., 2012). Although only one element (thistles) was studied here, 13 different species of coccinellids were found to be associated with this particular refuge (although only $H$. convergens and $H$. variegata were positively marked with $\mathrm{Rb}$, likely because these two species were the most common species at the study site). As future studies that include additional plant species are completed, further information will be gained that can be used to design mixed crop and refuge landscapes in central Chile. We show here how the maintenance of edges can be an important management tool in maintaining high densities of aphid predators for control purposes.

\section{Acknowledgments}

The author would like to thank Marcos Domínguez Muñoz for his valuable field and laboratory support and Cinthia Jara Peña of the Centro Tecnológico de Suelos y Cultivos (CTSyC), Universidad de Talca, for her support of this work. This study was financially supported by Fondecyt 1070412. 


\section{Resumen}

C.M. Villegas, J.A. Verdugo, A.A. Grez, J. Tapia y B. Lavandero. 2013. Movimiento entre cultivos y malezas: refugios temporales para insectos afidófagos en Chile Central. Cien. Inv. Agr. 40(2): 317-326. Los bordes de los cultivos tienen efectos importantes sobre las poblaciones de enemigos naturales, pudiendo actuar como una fuente o sumidero durante la temporada de crecimiento. Observaciones anteriores sugieren que algunos coccinélidos estarían asociados con el cardo mariano (Sylibum marianum (L.) Gaertn), una maleza común en el valle central de Chile. Para determinar si estos bordes de cardo son posibles refugios de enemigos naturales, se estimó la abundancia de coccinélidos a 0,10 y $25 \mathrm{~m}$ de distancia desde los bordes del cultivo en tres campos de alfalfa. Para estimar el movimiento de coccinélidos entre los bordes y la alfalfa, se llevaron a cabo estudios de marcaje-recaptura, usando el elemento traza rubidio $(\mathrm{Rb})$. Los coccinélidos más comunes fueron Hippodamia convergens (63\%), H. variegata (11\%), Rhyzobius lophantae (4\%) and Adalia angulifera (4\%). A mediados de noviembre, la abundancia de coccinélidos incrementó al borde del campo de alfalfa $(0 \mathrm{~m})$, comparado con mediciones al centro del campo (25 $\mathrm{m}$ desde el borde), coincidiendo con una disminución de áfidos en todos los puntos de muestreo. Un $68 \%$ de los coccinélidos capturados al borde de los cardos estaban marcados con rubidio, lo cual sugiere el movimiento desde la alfalfa hacia los cardos de los coccinélidos. Después de la remoción de los cardos, los coccinélidos regresaron al cultivo, definido por aquellos coccinélidos marcados colectados posteriormente en la alfalfa en las tres distancias de muestreo. Se sugiere que los cardos pueden actuar como un refugio para estos depredadores cuando los áfidos no se encuentran disponibles en los campos de alfalfa.

Palabras clave: Alfalfa, cardo, coccinélidos, refugios, rubidio.

\section{References}

Aguilera, A., C. Klein, and R. Rebolledo. 2005. Chinitas, símbolo del control biológico de plagas. Tierra Adentro 65:18-19.

Altieri, M., and C. Nicholls. 2010. Diseños agroecológicos para incrementar la biodiversidad de entomofauna benéfica en agroecosistemas. SOCLA 1:82.

Blackman, R.L., and V.F. Eastop. 2000. Aphids on the world's crops: an identification and information guide. Wiley, Chichester, West Sussex, England. $250 \mathrm{pp}$.

Burgio, G., R. Ferrari, L. Boriani, M. Pozzati, and J. Van Lenteren. 2006. The role of ecological infrastructures on Coccinellidae (Coleoptera) and other predators in weedy field margins within northern Italy agroecosystems. Bulletin of Insectology 59:59-67.

Devotto, M., and M. Gerding. 2000. Plagas de la Alfalfa. In: P. Soto (ed.). Alfalfa en la zona centro sur de Chile INIA, INIA Quilamapu. Chillán, Chile. 4: 109-124.

Elliott, N.C., R.W. Kieckhefer, G.J. Michels, and K.L. Giles. 2002. Predator abundance in alfalfa fields in relation to aphids, within-field vegetation, and landscape matrix. Environmental Entomology 31:253-260.

Fox, J. 2005. The R commander: A basic-statistics graphical user interface to R. Journal of Statistical Software 14:1-42.

Gaete, P. 2008. Utilización de rubidio para el marcaje de depredadores afidófagos en el cultivo de alfalfa (Medicago sativa). Tesis de Ingeniero Agrónomo. Facultad de Ciencias Agrarias. Universidad de Talca. Talca, Chile. 40 pp.

González, G. 2006. Los Coccinellidae de Chile. Available on line at http://www.coccinellidae.cl (Website accessed: November 24, 2011).

Grez, A.A., and E. Prado. 2000. Effect of plant patch shape and surrounding vegetation on the dynamics of predatory coccinellids and their prey Brevi- 
coryne brassicae (Hemiptera: Aphididae). Environmental Entomology 29:1244-1250.

Grez, A.A., C. Torres, T. Zaviezo, B. Lavandero, and M. Ramírez. 2010. Migration of coccinellids to alfalfa fields with varying adjacent vegetation in Central Chile. Ciencia e Investigación Agraria 37:111-121.

Grez, A.A., T. Zaviezo, S. Díaz, B. Camousseigt, and G. Cortés. 2008. Effects of habitat loss and fragmentation on the abundance and species richness of aphidophagous beetles and aphids in experimental alfalfa landscapes. European Journal of Entomology 105:411-420.

Grez, A.A., T. Zaviezo, and M. Ríos. 2005. Ladybird (Coleoptera : Coccinellidae) dispersal in experimental fragmented alfalfa landscapes. European Journal of Entomology 102:209-216.

Gurr, G.M., N.D. Barlow, J. Memmott, S.D. Wratten, and D.J. Greathead. 2000. A history of methodological, theoretical and empirical approaches to biological control. In: G.M. Gurr and S.D. Wratten (eds.). Biological Control: Measures of Success. Kluwer Academic Publishers. Dordrecht, The Netherlands. 436 pp.

Kobelt, A.J., A.L. Yen, and M. Kitching. 2009. Laboratory validation of rubidium marking of herbivorous insects and their predators. Australian Journal of Entomology 48:204-209.

Landis, D.A., S.D. Wratten, and G.M. Gurr. 2000. Habitat management to conserve natural enemies of arthropod pests in agriculture. Annual Review of Entomology 45:175-201.

Lavandero, B., S. Wratten, P. Shishehbor, and S. Worner. 2005. Enhancing the effectiveness of the parasitoid Diadegma semiclausum (Helen): Movement after use of nectar in the field. Biological Control 34:152-158.

Long, R., A. Corbett, C. Lamb, C. Reberg-Horton, J. Chandler, and M. Stimmann. 1998 Beneficial insects move from flowering plants to nearby crops. California Agriculture 52:23-26.

Lundgren, J.G. 2009. Nutritional aspects of non-prey foods in the life histories of predaceous Coccinellidae. Biological Control 51:294-305.

Marshall, E.J.R., and A.C. Moonen. 2002. Field margins in northern Europe: their functions and in- teractions with agriculture. Agriculture Ecosystems \& Environment 89:5-21.

Mensah, R., and R. Sequeria. 2004. Habitat manipulation for insect pest management in cotton cropping systems. In: G.S. Gurr, S. Wratten and M. Altieri (eds.). Ecological Engineering for Pest Management: Advances in Habitat Manipulation for Arthropods. Csiro Publishing. Collingwood, Australia. $225 \mathrm{pp}$

Polavarapu, S., G.C. Lonergan, and W.D. Seabrook. 1992. Labeling the blueberry leaftier, Croesia curvalana with foliar sprays of rubidium chloride. Entomologia Experimentalis et Applicata 63:143-153.

Prasifka, J.R., K.M. Heinz, and C.G. Sansone. 2001. Field testing rubidium marking for quantifying intercrop movement of predatory arthropods. Environmental Entomology 30:711-719.

Scherber, C., B. Lavandero, K.M. Meyer, D. Perovic, U. Visser, K. Wiegand, and T. Tscharntke. 2012. Scale Effects in Biodiversity and Biological Control: Methods and Statistical Analysis: In: G.M. Gurr, S. Wratten, W.E. Snyder, and D. Read (eds.). Biodiversity and Insect Pests: Key Issues for Sustainable Management. John Wiley and Sons, Ltd. London, UK. p.121-138.

Schmidt, M., C. Thies, and T. Tscharntke. 2004. The landscape context of arthropod biological control: In: G.M. Gurr, S. Wratten, and M. Altieri (eds.). Ecological Engineering for Pest Management: Advances in Habitat Manipulation for Arthropods. Csiro Publishing, Collingwood, Australia. $225 \mathrm{pp}$.

Skirvin, D.J., L. Kravar-Garde, K. Reynolds, C. Wright, and A. Mead. 2011. The effect of within-crop habitat manipulations on the conservation biological control of aphids in field-grown lettuce. Bulletin of Entomological Research 101:623-631.

Sutherland, J.P., M.S. Sullivan, and G.M. Poppy. 2001. Distribution and abundance of aphidophagous hoverflies (Diptera: Syrphidae) in wildflower patches and field margin habitats. Agricultural and Forest Entomology 3:57-64.

Thies, C., I. Steffan-Dewenter, and T. Tscharntke. 2008. Interannual landscape changes influence 
plant-herbivore-parasitoid interactions. Agriculture Ecosystems \& Environment 125:266-268.

Woodcock, B.A., J. Redhead, A.J. Vanbergen, L. Hulmes, S. Hulmes, J. Peyton, M. Nowakowski, R.F. Pywell, and M.S. Heard. 2010. Impact of habitat type and landscape structure on biomass, species richness and functional diversity of ground beetles. Agriculture Ecosystems \& Environment 139:181-186. 